\title{
Studi Kasus Tentang Metode Tutor Sebaya Terhadap Prestasi Belajar
}

\author{
Yuliana Puspitasari ${ }^{1 *}$, Rahmat Rais ${ }^{2}$, Kiswoyo $^{3}$ \\ 123 Pendidikan Guru Sekolah Dasar, Fakultas Ilmu Pendidikan, Universitas PGRI Semarang
}

\section{A R T I C L E I N F O \\ Article history: \\ Received 10 February 2019 \\ Received in revised form 09 March 2019 \\ Accepted 15 April 2019 \\ Available online 25 May 2019}

\section{Kata Kunci:}

Studi Kasus, Tutor Sebaya,

Prestasi Belajar

Keywords:

case study, a tutorage,

learning achievements

\begin{abstract}
A B S T R A K
Penelitian ini bertujuan untuk mengetahui bagaimana proses perencanaan metode tutor sebaya, pelaksanaan metode tutor sebaya dan untuk mengetahui pengaruh metode tutor sebaya terhadap prestasi belajar siswa. Jenis penelitian ini adalah penelitian kualitatif dengan pendekatan studi kasus yang menggunakan data berupa informasi yang berdasarkan temuan-temuan di lapangan. Populasi penelitian adalah siswa kelas V SDN Kembangarum 4 Kecamatan Mranggen Kabupaten Demak. Sample yang diambil adalah 4 siswa yang menjadi tutor dan 4 siswa yang di bimbing, dengan menggunakan teknik analisis deskriptif fenomenologis. Data penelitian diperoleh melalui observasi, wawancara dan dokumentasi. Dapat disimpulkan bahwa penerapan metode tutor sebaya dapat meningkatkan prestasi belajar siswa kelas $\mathrm{V}$ dengan bukti nilai rata-rata siswa kondisi awal 59,42 meningkat menjadi 78,19 setelah diterapkan metode tutor sebaya. Melaui perencanaan penerapan metode tutor sebaya guru sebelumnya mengenali
\end{abstract} karakteristik siswa sehingga guru memilih untuk menerapkan metode tutor sebaya. Dalam pelaksanaan guru memberikan intruksi kepada siswa sebelum menerapkan metode tutor. Siswa yang dianggap pandai dipilih sebagai tutor. Berdasarkan hasil penelitian ini saran yang dapat disampaikan adalah penerapan metode tutor sebaya dapat berlangsung lebih efektif.

\begin{abstract}
A B S T R A C T
This study attempts to find out how the planning process method peers, the implementation of a method of guidance peer and to know the influence of a method of guidance peer against student learning achievements. The kind of this research is the qualitative study with the approach of a case study using data of the information based on discoveries in the field. The population research is students grade 5 SDN Kembangarum 4 sub-district of mranggen, district demak. The Sample taken is 4 the students who were a tutor and 4 students in the guide, with using a technique descriptive analysis phenomenology. Laboratory data obtained through observation, interviews, and documentation. Can be concluded the application of a method of a tutorage can increase student learning achievements grade 5 a student average score the initial conditions 59,42 increased to 78,19 afterward applied a method of a tutorage. That planning the application of a method of a tutorage teacher formerly recognize the characteristics of students so teachers choose to apply the methods of a tutorage. In the implementation of the teachers give instructions to students before applies the methods of a tutor. Students who were deemed was chosen as a tutor.. Based on the result of this research advice to report is the application of a method of a tutorage can last more effective
\end{abstract}

\section{Pendahuluan}

Pendidikan adalah hal terpenting bagi setiap negara untuk dapat berkembang pesat. Negara yang hebat akan menempatkan pendidikan sebagai prioritas pertamanya, karena dengan pendidikan, kemiskinan pada rakyat di negara tersebut akan dapat tergantikan menjadi kesejahteraan. Bagaimanapun, dalam perkembangannya, pendidikan di Indonesia senantiasa harus menghadapi beberapa masalah di setiap tahapnya. Masalah-masalah tersebut hanya dapat diselesaikan dengan partisipasi dari semua pihak yang terkait di dalam sistem pendidikan, seperti orang tua, guru-guru, kepala sekolah, masyarakat, dan

Copyright (C) Universitas Pendidikan Ganesha. All rights reserved. 
juga peserta didik itu sendiri. Pada fase input, orang tua memiliki kontribusi besar dalam memperkenalkan nilai-nilai baik kepada anak-anak mereka. Orang tua bertanggung jawab penuh untuk mendidik anak-anak mereka dengan nilai-nilai kepemimpinan, sehingga mereka mempunyai bekal yang cukup untuk menjadi cikal bakal pemimpin ketika mereka mulai memasuki institusi formal, seperti sekolah. Pada fase proses, orang tua bekerjasama dengan para guru dan kepala sekolah untuk memberikan penguatan kepada peserta didik dalam menerapkan nilai-nilai kepempinan yang baik melalui budaya organisasi di sekolah (Megawanti, 2012)

Depdiknas (2003) Pasal 3 menyatakan bahwa Pendidikan berfungsi mengembangkan kemampuan dan membentuk bangsa yang bermatabat dalam rangka mencerdaskan kehidupan bangsa yang tertujuan untuk berkembangnya potensi peserta didik agar menjadi manusia beriman dan bertakwa kepada Tuhan Yang Maha Esa, berakhlak mulia, sehat, berilmu, cakap, kreatif, mandiri, dan menjadi warga negara yang demokratis serta bertanggung jawab.

Armawan (2013) mengatakan bahwa Pendidikan merupakan urusan manusia, hanya manusialah yang memiliki subyek dan obyek pendidikan adalah manusia. Yang mendidik adalah manusia dan yang di didik juga manusia. Pendidikan merupakan komunikasi yang otentik cara berada manusia kepada manusia muda agar supaya dimiliki, dilanjutkan, dan disempurnakan. Dalam hal ini anak didik disebut sebagai generasi penerus dan mengembangkan cara berada manusia. Cara berada manusia itu berupa nilai-nilai, sesuatu yang berharga atau hasil budi daya manusia.

Menurut R. Gagne dalam (Susanto, 2015: 1) mengatakan “ Belajar dapat didefinisikan sebagai suatu proses di mana suatu organisme berubah perilakunya sebagai akibat pengalaman". Adapun menurut Burton Usman dan Setiawati (1993:4) "Belajar dapat diartikan sebagai perubahan tingkah laku pada diri individu berkat adanya interaksi antara individu dengan individu lain dan individu dengan lingkungannya sehingga mereka lebih mampu berinteraksi dengan lingkungannya". Sementara menurut E.R Hilgard (dalam Susanto, 2015:3) mengatakan "Belajar adalah suatu perubahan kegiatan reaksi terhadap lingkungan. Perubahan yang dimaksud mencakup pengetahuan, kecakapan, tingkah laku dan ini diperoleh melalui latihan (pengalaman)".

Prestasi adalah hasil suatu kegiatan yang telah dikerjakan, diciptakan, baik secara individu maupun secara kelompok. Prestasi tidak akan pernah dihasilkan selama seseorang tidak melakukan kegiatan. Prestasi belajar dibidang pendidikan adalah hasil dari pengukuran terhadap siswa yang meliputi faktor kognitif, afektif dan psikomotor setelah mengikuti proses pembelajaran yang diukur dengan menggunakan instrumen tes atau instrumen yang releven (Hamdani, 2011).

(Hamdani, 2011: 80) mengatakan bahwa "metode pembelajaran adalah cara yang digunakan guru untuk menyampaikan pelajaran kepada siswa". Darsono (2000:24), Mengatakan bahwa "pembelajaran adalah suatu kegiatan yang dilakukan guru dengan sedemikian rupa, sehingga tingkah laku siswa berubah kearah yang lebih baik". Karena penyampaian itu berlangsung dalam interaksi edukatif, metode pembelajaran dapat diartikan sebagai cara yang dipergunakan oleh guru dalam proses pembelajaran di kelas. Dalam pemilihan metode apa yang tepat, guru harus melihat situasi dan kondisi siswa serta materi yang diajarkan. Dalam kegiatan belajar mengajar daya serap peserta didik tidaklah sama. Dalam menghadapi perbedaan tersebut, strategi pengajaran yang tepat sangat dibutuhkan. Strategi belajar mengajar adalah pemilihan jenis latihan tertentu yang cocok dengan tujuan yang akan di capai (Hamdani, 2011: 19).

Guru kelas V di SDN Kembangarum 4 dalam proses pembelajaran didalam kelas sudah menerapkan beberapa strategi. Model dan metode pembelajaran telah diterapkan oleh guru sesuai dengan situasi, kondisi dan materi yang akan diajarkan dalam kegiatan. siswa kelas V termasuk dalam masa kanak-kanak akhir yang memiliki karakteritik senang bermain dengan teman sebayanya. Mengingat bahwa setiap siswa memiliki karakteristik dan perkembangan yang berbeda-beda. Oleh karena itu, dalam proses pembelajaran di kelas guru dituntut untuk menggunakan berbagai metode pembelajaran atau strategi tertentu untuk meningkatkan hasil belajar peserta didik. Guru juga dituntut untuk kreatif dalam memilih metode pembelajaran yang sesuai dengan kondisi siswa. Dalam pembelajaran siswa sulit terangsang untuk mengajukan pertanyaan kepada guru. Selama proses diskusi berlangsung beberapa siswa hanya mengandalkan siswa yang pandai untuk mengerjakan tugas yang diberikan oleh guru. Sesuai dengan hasil ulangan tengah semester genap nilai rata-rata mata pelajaran matematika siswa kelas $V$ mendapatkan hasil yang sedang diatas kriteria ketuntasan minimal yaitu 70. Oleh sebab itu, perlu adanya tindakan tes hasil belajar siswa untuk mencapai kriteria tersebut. Menyadari permasalahan tersebut, perlu adanya strategi pembelajaran yang menarik.

Karakteristik siswa yang senang bergaul dengan teman sebaya dan bekerjasama sangat tepat apabila dilakukan pembelajaran secara berkelompok. Salah satunya dengan menggunakan metode tutor sebaya. Metode tutor sebaya adalah salah satu contoh metode yang diterapkan oleh guru pada saat kegiatan belajar mengajar. Melalui penerapan metode tutor sebaya, proses pembelajaran lebih nampak pada mata pelajaran matematika. 
Suherman (2003:45) menjelaskan metode tutor sebaya sebagai metode pembelajaran dimana sekelompok siswa yang telah tuntas terhadap bahan pelajaran, memberikan bantuan kepada siswa yang mengalami kesulitan dalam memahami bahan pelajaran yang dipelajarinya. Inti dari metode pembelajaran tutor sebaya dikemukakan oleh Nisa (2014) adalah pembelajaran yang pelaksanaannya dengan membagi kelas dalam kelompok-kelompok kecil, yang sumber belajarnya bukan hanya guru melainkan juga teman sebaya yang pandai dan cepat dalam menguasai suatu materi tertentu. Metode pembelajaran tutor sebaya juga dapat meminimalisir dominasi guru dalam pembelajaran sebagaimana menjadi ciri khas pembelajaran konvensional. Paradigma pembelajaran era modern mensyaratkan bahwa guru hanya menjadi fasilitator yang dapat memotivasi pengembangan musikalitas siswa, misalnya dengan memberikan kesempatan pada siswa untuk melakukan kegiatan-kegiatan bermain musik sebanyakbanyaknya, membiarkan siswa bekerja dalam kelompok kecil, membiarkan siswa bekerja dengan ide-ide mereka dan mengalami yang telah mereka miliki, memberikan batas-batas materi pembelajaran yang jelas, meningkatkan rasa ingin tahu dan pemahaman mereka tentang pelajaran musik dengan mengajukan pertanyaan-pertanyaan (Hendriansyah, 2013).

Adapaun kelebihan metode tutor sebaya menurut Nisa (2014) adalah: tutor Sebaya akan merasa bangga atas perannya dan juga belajar dari pengalamannya, anak-anak diajarkan untuk mandiri, siswa lebih mudah dan leluasa dalam menyampaikan masalah yang dihadapi sehingga siswa yang bersangkutan terpacu semangatnya untuk mempelajari materi ajar dengan baik, membuat siswa yang kurang aktif menjadi aktif karena tidak malu lagi untuk bertanya dan mengeluarkan pendapat secara bebas, membantu siswa yang kurang mampu atau kurang cepat menerima pelajaran dari gurunya, dan Tutor maupun yang ditutori sama-sama mendapat pengalamann dan yang ditutori akan lebih kreatif dalam menerima pelajaran. Selain itu, kelemahan Tutor Sebaya adalah: tidak semua siswa dapat menjelaskan kepada temannya dan tidak semua siswa dapat menjawab pertanyaan temannya (Suzar'an, 2016) Kelebihan dari pendekatan tutor sebaya ini adalah dapat melatih siswa dalam memecahkan masalah, mengatasi kesulitannya sendiri dan mampu membimbing diri sendiri. Selain itu karena tutor berasal dari teman sekelasnya maka siswa tidak merasa malu atau segan untuk bertanya apabila ada hal-hal yang kurang dimengerti dalam proses belajar mengajar (Sukayasa, 2016)

(Armawan, 2013) yang berpendapat bahwa penggunaan tutor sebaya yang dipilih dari teman mereka sendiri dalam satu kelas akan memungkinkan peserta didik tidak merasa enggan dalam bertanya sehingga kegiatan tersebut memungkinkan terjadinya peningkatan kualitas dalam pembelajara. Sejathi, (2011) juga menambahkan bahwa salah satu keunggulan penerapan model tutor sebaya dalam pembelajaran adalah dengan penerapan model tutor sebaya dapat memperkuat hubungan antara sesama peserta didik sehingga dapat mempertebal perasaan sosial (Sholi, 2015)

Kegiatan belajar mengajar dikelas $\mathrm{V}$ yang selama ini pasif semula menjadi sedikit lebih aktif akibat penerapan metode tutor sebaya yang dilakukan oleh guru kelas V. Hal tersebut berdampak pada prestasi belajar siswa yang meningkat. Meski begitu, ada beberapa kendala yang dihadapi oleh guru maupun siswa dalam penerapan metode tersebut. Metode pembelajaran yang dipilih harus mengutamakan peran siswa dalam pembelajaran dan kerjasama kelompok secara baik tanpa menghilangkan tanggung jawab masingmasing anggota kelompok. Metode ini dapat menarik perhatian siswa dan meningkatkan semangat belajar siswa. Guru sering menggunakan beberapa metode pembelajaran dalam pembelajaran matematika. Salah satu metode pembelajaran yang sesuai dengan kondisi siswa kelas V SDN Kembangarum 4 yaitu metode tutor sebaya. Tutor sebaya bukanlah metode pembelajaran yang baru, melainkan sebuah metode pembelajaran lama yang seringkali digunakan tetapi tidak efektif, karena dulu belajar berpusat pada guru (teacher centered). Tetapi karena saat ini belajar berpusat pada siswa (student centered), maka penggunaan tutor sebaya sebagai metode pembelajaran dapat efektif digunakan (Nisa, 2014)

Dalam penerapannya, metode tutor sebaya memiliki banyak kendala yang dihadapi baik pada saat perencanaan maupun pada saat proses pelaksanaan, karena sebagai guru harus dapat menerapkan metode pembelajaran yang sesuai dengan kemampuan siswa sehingga dapat tercapainya tujuan pembelajaran sesuai dengan ketentuan yang telah ditentukan. Berangkat dari konteks penelitian tersebut, maka peneliti tertarik untuk melakukan penelitian tentang metode pembelajaran tutor sebaya di kelas $\mathrm{V}$ SDN Kembangarum 4 Kecamatan Mranggen Kabupaten Demak.

Secara umum tujuan penelitian ini adalah untuk mendapatkan informasi, gambaran dan pengetahuan yang akurat tentang pergaulan teman sebaya terhadap prestasi belajar siswa. Sehingga tujuan penelitian ini adalah : Untuk mengetahui bagaimana proses perencanaan penerapan metode tutor sebaya terhadap prestasi belajar siswa kelas V SDN Kembangarum 4 Kecamatan Mranggen Kabupaten Demak, Untuk mengetahui bagaimana proses pelaksanaan penerapan metode tutor sebaya terhadap prestasi belajar siswa kelas V SDN Kembangarum 4 Kecamatan Mranggen Kabupaten Demak dan untuk mengetahui bagaimana pengaruh metode tutor sebaya terhadap prestasi belajar siswa kelas V SDN Kembangarum 4 Kecamatan Mranggen Kabupaten Demak. 


\section{Metode}

Jenis penelitian ini adalah penelitian kualitatif dengan pendekatan studi kasus. (Hamdani, 2011:162) mengatakan bahwa "studi kasus adalah salah satu penelitian dalam bidang sosial. Metode ini berbentuk penjelasan tentang masalah, kejadian, atau situasi tertentu". Iskandar (2013:206)mengatakan bahwa "studi kasus bertujuan untuk mengembangkan metode kerja yang paling efisien, maknanya peneliti melakukan telaah secara mendalam tentang suatu kasus, kesimpulan hanya berlaku pada kasus tertentu saja".

Jenis penelitian kualitatif adalah jenis penelitian yang menggunakan data berupa informasi yang berdasarkan temuan-temuan di lapangan. Iskandar (2013:206) mengatakan bahwa "penelitian fenomologis adalah menafsirkan arti dari peristiwa-peristiwa, fenomena-fenomena, dan hubungan dengan orang-orang yang biasa dalam situasi tertentu". Fenomologis yaitu mendeskripsikan temuantemuan yang ada di lapangan untuk mendapatkan gambaran yang objektif tentang suatu kasus yang diteliti. Pendekatan studi kasus dimaksudkan suatu penelitian yang akan mempelajari secara mendalam tentang studi kasus metode pembelajaran tutor sebaya terhadap prestasi belajar siswa kelas V SDN Kembangarum 4 Kecamatan Mranggen Kabupaten Demak.

Subyek penelitian adalah siswa kelas V SDN Kembangarum 4 Kecamatan Mranggen Kabupaten Demak dengan mengumpulkan data tentang pemilihan metode pembelajaran tutor sebaya melalui informasi dari informan yang mengenali subyek. Subyek penelitian yaitu siswa kelas V SDN Kembangarum 4 Kecamatan Mranggen Kabupaten Demak yang memiliki peningkatan prestasi belajar karena pengaruh dari pemilihan metode pembelajaran tutor sebaya yang diterapkan oleh guru dalam kegiatan belajar mengajar di kelas.

Keabsahan data diperlukan untuk memperoleh data yang sahih yang akan dianalisis dalam penelitian. Keabsahan data berguna untuk menetapkan keabsahan data yang diperlukan dalam teknik pemeriksaan data didasarkan atas sejumlah kriteria tertentu. Teknik pemeriksaan keabsahan data dalam penelitian ini yaitu dengan menggunakan triangulasi teknik dan triangulasi sumber. Moleong (2002:178) mengatakan "triangulasi adalah teknik pemeriksaan keabsahan data yang memanfaatkan sesuatu yang lain di luar data itu untuk keperluan pengecekan atau sebagai pembanding terhadap data itu". Triangulasi diartikan sebagai teknik pengumpulan data yang bersifat menggabungkan dari berbagai teknik pengumpulan data dan sumber data yang telah ada. Triangulasi teknik berarti peneliti menggunakan teknik pengumpulan data yang berbeda-beda untuk mendapatkan data dari sumber yang sama. Triangulasi sumber berarti mendapatkan data dari berbagai sumber yang berbeda-beda dengan teknik yang sama. (Sugiono, 2016:330)

Teknik analisis data yang digunakan dalam penelitian ini adalah teknik analisis deskriptif fenomenologis. Moleong (2002:9)mengatakan "pandangan fenomenologis berusaha memahami arti peristiwa dan kaitan-kaitannya terhadap orang-orang biasa dalam situasi tertentu". Berdasarkan teori yang dikemukakan dapat disimpulkan bahwa fenomenologis yaitu mengungkap konsep pengalaman yang terjadi pada beberapa individu dalam situasi yang dialami sehingga tidak ada batasan dalam memaknai fenomena yang dikaji. Teknik fenomenologi dalam penelitian ini digunakan untuk mendeskripsikn gambaran mengenai peningkatan prestasi belajar siswa akibat pengaruh dari penerapan metode pembelajaran tutor sebaya. Berbagai data tentang peningkatan prestasi belajar yang terpengaruh oleh metode pembelajaran tutor sebaya yang dipillih oleh guru. Diharapkan ada temuan-temuan dilapangan yang meliputi prestasi belajar siswa kelas $V$ yang terpengaruh dengan penerapan metode tutor sebaya yang diterapkan oleh guru dalam proses pembelajaran. Untuk selanjutnya, dikategorikan, dianalisis, dan disimpulkan sehingga dapat menjawab permasalahan yang ada di dalam penelitian ini.

\section{Hasil dan Pembahasan}

Data yang diperoleh merupakan data yang didapatkan dengan cara observasi, wawancara dan dokumentasi. Dalam hal ini wawancara merupakan data primer yang penting karena menjadi bagian utama dalam kegiatan analisis dan pembahasan data sedangkan hasil catatan lapangan merupakan data pendukung yang dibuat oleh peneliti pada saat melakukan kegiatan observasi. Sejumlah pertanyaan wawancara yang termuat dalam instrumen wawancara telah dikembangkan lebih lanjut dalam penelitian dan dalam proses pengambilan data dari pihak terwawancara. Sesuai dengan kebutuhan peneliti, informasi yang terkumpul diperoleh dari beberapa sumber yaitu Guru Kelas V sebagai informan utama dan sebagai informan pendukung peneliti untuk mengadakan wawancara dengan Kepala Sekolah, 8 siswa kelas V dan 4 wali murid. Dari 14 Informan yang dipilih oleh peneliti dimaksudkan untuk menggali informasi selengkap-lengkapnya.

Suatu pembelajaran dapat berjalan dengan efektif jika siswa-siswinya merasakan kesenangan dalam kegiatan pembelajaran. Kebanyakan siswa kelas $\mathrm{V}$ masih malu dan takut bertanya kepada guru. Untuk kelas V guru lebih memilih metode pembelajaran tutor sebaya. Metode tutor sebaya ini lebih ditekankan pada mata pelajaran matematika karena dalam kurikulum 2013 mata pelajaran matematika 
itu berdiri sendiri. Selama proses pembelajaran berlangsung hanya 50\% yang masih pasif, hal ini dikarenakan faktor malu dan takut untuk bertanya dengan gurunya. Sehingga guru kelas V menindaklanjuti dengan membagi kelas menjadi 4 kelompok, masing-masing kelompok beranggotakan 5 sampai 6 siswa. Guru menghandalkan satu siswa untuk menjadi tutor dimasing-masing kelompoknya. Pada saat proses pembelajaran tutor sebaya itu ternyata banyak siswa yang awalnya pasif menjadi aktif meskipun belum $100 \%$ siswa aktif semua. Hasilnya banyak siswa yang bertanya dengan temannya namun ketika guru meninggalkan kelas dan mengintip melalui jendela sehingga dapat mengetahui mana siswa yang aktif dan mana siswa yang pasif serta kesulitan yang dihadapi siswa ketika menjadi tutor dalam kelompoknya. Pertama, teman yang kurang mampu tidak mau bertanya dengan tutor, hal ini membuat tutor menjadi takut jika diberi tanggung jawab ternyata belum bisa. Kedua, jika tutor memberi tahu mengenai materi yang kurang bisa kepada teman yang kurang mampu ternyata teman yang kurang mampu tersebut malah ngeyel atau membantah. Ketiga, tutor belum menguasai materi hal tersebut membuat tutor kebingungan ketika akan mengajari temannya yang kurang mampu dalam memahami materi. Namun tutor memiliki rasa ingin tahu yang tinggi dengan cara bertanya kepada guru. Keempat, teman yang diajari oleh tutor sering kesulitan memahami kata-kata tutor yang kurang jelas, hal ini membuat tutor mengalami kesulitan dalam mengajari temannya yang kurang mampu. Dari beberapa kesulitan yang dihadapi oleh tutor saat mengajari temannya, tidak membuat temannya $100 \%$ tidak memahami materi melainkan ada dampak positif bagi temannya yang kurang mampu dalam memahami materi. Teman yang pernah diajari oleh tutor tingkat pemahamannya sudah cukup baik, namun terkadang ada beberapa siswa yang paham apabila dijelaskan oleh guru, dikarenakan pada saat menjelaskan katakata guru lebih mudah dipahami. Tetapi kembali lagi ke karakteristik siswa yang berbeda-beda sehingga penerapan metode tutor sebaya ini ada yang cocok dan sebaliknya.

Menurut beberapa siswa yang peneliti wawancarai banyak yang merasakan bahwa suasana pembelajaran dengan metode tutor sebaya berlangsung sangat menyenangkan, ramai, bahagia dan terkadang jika ditinggal oleh guru. Ada beberapa siswa yang suka lari-lari sendiri bahkan mengajak temannya bermain. Hasil dokumentasi mayoritas siswa yang prestasinya kurang baik ada pada siswa lakilaki dan perempuan. Dan juga siswa laki-laki dan perempuan yang menduduki rangking 5 besar. Faktor lain yang mempengaruhi prestasi belajar siswa yaitu kesadaran siswa itu sendiri bahwa dia memiliki tanggung jawab untuk belajar, dari hasil wawancara yang peneliti lakukan hanya ada beberapa siswa yang memiliki kesadaran sendiri untuk belajar. Untuk yang lainnya daari dorongan orang tua, ada beberapa dengan kesadaran diri sendiri serta dari dorongan orang tua.

Penerapan metode pembelajaran tutor sebaya dapat mempengaruhi prestasi belajar siswa. Guru mengatakan bahwa anak-anak pasti tertarik dengan penerapan metode pembejaran yang baru. Hal itu dapat menyebabkan motivasi belajar siswa meningkat sehingga berpengaruh pada prestasi belajar siswa yang cukup baik. Kemudian pengaruh positif lainnya yaitu membuat siswa yang awalnya pasif menjadi lebih aktif dan tidak malu serta berani untuk mengajukan pertanyaan dalam kegiatan pembelajaran. Peningkatan prestasi belajar siswa dapat dilihat bahwa nilai rata-rata siswa sebelum diterapkan metode tutor sebaya yaitu 59,42. Nilai tertinggi adalah 100 dan nilai terendah adalah 20. Pada tahap pra tindakan terdapat 5 siswa yang nilainya mencapai KKM, sedangkan 16 siswa nilainya masih berada di bawah KKM dan yang mendapat nilai tuntas sesuai kriteria ketuntasan minimal hanya 5 siswa. penerapan metode tutor sebaya mengakibatkan nilai rata-rata siswa mengalami peningkatan dari kondisi awal 59,42 meningkat menjadi 78,19. Setelah diterapkan metode tutor sebaya terdapat 16 siswa yang nilainya mencapai KKM, sedangkan 5 siswa nilainya masih berada di bawah KKM. Nilai tertinggi adalah 100 dan nilai terendah adalah 50. Dari hasil pembelajaran dengan menerapkan metode tutor sebaya dapat disimpulkan bahwa pembelajaran dengan menggunakan metode tutor sebaya yang diterapkan guru dapat meningkatkan prestasi belajar siswa di kelas V.

\section{Simpulan dan Saran}

Hasil analisis data dan pembahasan yang telah dipaparkan sebelumnya dapat disimpulkan bahwa metode tutor sebaya berpengaruh terhadap prestasi belajar siswa kelas V SDN Kembangarum 4 Kecamatan Mranggen Kabupaten Demak. Hal ini melalui tahapan yang diawali dengan perencanaan penerapan metode tutor sebaya di kelas V. Di mana guru sebelumnya mengenali karakteristik peserta didik kelas $\mathrm{V}$ yang memiliki tingkat kecerdasan yang baik sehingga guru memilih untuk menerapkan metode tutor sebaya sehingga siswa yang mampu menguasai materi dijadikan sebagai tutor.

Dalam tahapan pelaksanaan metode pembelajaran tutor sebaya guru memberikan instruksi kepada siswa sebelum menerapkan metode tersebut. Siswa yang dianggap pandai dipilih sebagai tutor, ada beberapa kesulitan yang dialami tutor dalam kelompoknya antara lain teman yang dibimbing tidak mau nurut dan menyanggah. Untuk siswa yang dibimbing merasa lebih paham apabila dijelaskan oleh tutor yang ada di kelompoknya daripada penjelasan dari guru.. Kepala sekolah SDN Kembangarum 4 Kecamatan Mranggen Kabupaten Demak menerapkan 4 kompetensi (pedagogik, profesional, kepribadian dan sosial) 
yang harus dimiliki oleh guru-guru untuk meningkatkan kinerja guru dalam kegiatan belajar mengajar. Wali murid kelas V selalu memberikan dorongan belajar kepada anaknya agar dapat mencapai tujuan pembelajaran yang efektif. Adapun saran yang dapat disampaikan berdasarkan hasil dan pembahsan penelitian adalah sebagai berikut: 1) kepada siswa, melalui tutor sebaya diharapkan siswa lebih proaktif dalam belajar dan dapat meningkatkan motivasi belajar. 2) kepada guru, guru hendaknya memilih tutor yang kiranya mampu memotivasi rekannya dan mau berbagi dengan ilmu yang yang dimilikinya. 3) kepala sekolah, kepala sekolah memberikan kesempatan lebih banyak lagi kepada guru untuk mengembangkan potensi yang dimiliki sehingga dapat meningkatkan kualitas pembelajaran. 4) peneliti lain, peneliti lain diharapkan bisa menggunakan penelitian ini sebagai referensi untuk mengembangkan penelitian lebih lanjut.

\section{DAFTAR RUJUKAN}

Armawan, M. (2013). Penerapan Pembelajaran Metode Tutor Sebaya dan Learning Contracts Untuk Meningkatkan Hasil Belajar Siswa Pada Mata Pelajaran Matematika Kelas IV A MI Islamiyah Sukun Malang. Retrieved from Fakultas Ilmu Tarbiyah dan Keguruan UIN Maulana Malik Ibrahim Malang website: https://etheses.uin-malang.ac.id.

Darsono, M. (2000). Belajar dan Pembelajaran. Semarang: CV. IKIP Semarang PRESS.

Depdiknas. (2003). Undang-undang RI Nomor 20 Tahun 2003 Tentang Sistem Pendidikan Nasional. Jakarta: Depdiknas.

Hamdani. (2011). Strategi Belajar Mengajar. Bandung: Pustaka Setia.

Hendriansyah, D. (2013). Penerapan Metode Pembelajaran Tutor Sebaya Dalam Meningkatkan Keterampilan Bermain Ornamen Suling Lubang Enam. Jurnal Universitas Pendidikan Indonesia, 1(3). Iskandar. (2013). Metodologi Penelitian Pendidikan dan Sosial. Jakarta: Referensi.

Megawanti, P. (2012). Meretas Permasalahan Pendidikan Di Indonesia. Jurnal Formatif, 2(3).

Moleong, L. (2002). Metodologi Penelitian Kualitatif. Bandung: PT Remaja Rosdakarya.

Nisa, Y. (2014). Peer Teaching (Tutor Sebaya) Sebagai Metode Pembelajaran Untuk Melatih Siswa Mengajar. Jurnal Pendidikan Ekonomi Unswagati, 2(2).

Sejathi. (2011). Faktor-faktor yang mempengaruhi Efektivitas Pembelajaran.

Setiawati dan Usman. (1993). Upaya Optimalisasi Kegiatan Belajar Mengajar. Bandung: Remaja Rosdakarya.

Sholi, N. (2015). Penerapan Model Tutor Sebaya pada Mata Pelajaran Bahasa Inggris Reported Speech terhadap Hasil Belajar Peserta didik MAN Kota Probolinggo. Jurnal Kebijakan Dan Pengembangan Pendidikan, 1(1), 126-132.

Sugiyono. (2016). Metodologi Pendidikan. Bandung: Alfabeta.

Suherman, E. dkk. (2003). Strategi Pembelajaran Matematika Kontemporer. Bandung: PT Remaja Rosdakarya.

Sukayasa. (2016). Penerapan Model Pembelajaran Tutor Sebaya Untuk Meningkatkan Hasil Belajar Siswa Kelas V SDN 20 Toli-Toli Pada Operasi Hitung Campuran Bilangan Bulat. Jurnal Kreatif Tadulako Online, 4(9).

Susanto, A. (2015). Teori Belajar dan Pembelajaran di Sekolah Dasar. Jakarta: Prenadamedia Grup. Suzar'an, S. (2016). Efektifitas Metode Tutor Teman Sebaya Untuk Meningkatkan Kemampuan Mandi Anak Tunagrahita Sedang X. Jurnal Jurnal Ilmiah Pendidikan Khusus, 5(1). 